\title{
Appel Botha Cornelitz: the abc of a three hundred year old divorce case.
}

\author{
Jaco M. Greeff* \& J. Christoff Erasmus
}

Department of Genetics, University of Pretoria, Pretoria 0002, South Africa.

*Corresponding author:

Jaco .M. Greeff

Email: jaco.greeff@up.ac.za

Tel: +27832578761

Department of Genetics, University of Pretoria, Pretoria 0002, South Africa

\section{J. Christoff Erasmus}

Email: christoff.erasmus@gmail.com

Department of Genetics, University of Pretoria, Pretoria 0002, South Africa

\begin{abstract}
A B S T R A C T
In 1683 Maria Kickers and Jan Cornelitz got married in Cape Town. Today, 330 years later, the living patrilineal descendants of Maria's four sons, number in excess of 76,000 people.

Curiously, none of them carry the surname Cornelitz - in fact, they are all called Botha and include former President P. W. Botha, general Louis Botha and Minister Pik Botha. The reason for this anomaly is also the reason why Jan got divorced from Maria in 1700. According to Maria's testimonies she did indeed have a long term relationship with Frederik Botha, but in her defence she claimed that her husband was impotent and that he actually encouraged her. Other witnesses, presumably prompted by Jan, gave testimonies that implied that Maria was in fact licentious. We combined haplotyping with the AmpFlSTR® Y filer ${ }^{\mathrm{TM}}$ kit with deep-rooting genealogies to show that Maria's first son was actually fathered by Ferdinandus Appel and that roughly half the living Bothas (38,000 people) actually descend from Ferdinandus Appel while the remaining three sons all stem from the same father, presumably Frederik Botha, and this implies that Maria's husband did not father any of her sons.
\end{abstract}

Keywords: Y-STR; Afrikaner; non-paternity; adultery; pedigrees; genealogy 


\section{Introduction}

DNA evidence has been used to confirm paternity of a few historically significant people by genotyping living descendants [1,2] or the actual remains of people concerned [3,4]. One of the earliest contested paternities at the Cape of Good Hope involved not just one, but the first seven children of Maria Kickers and resulted in a divorce from her husband, Jan Cornelitz, three hundred and thirteen years ago [5,6,7, Supplementary Table 1]. At the time it must have been a sensational affair as the divorce was preceded by 15 years of adulterous relationships [7, Supplementary Table 1] and it was one of only four divorces in the first 50 years of the Cape colony's existence [6]. Here we use DNA from descendants as many as 10 generations later to unravel the paternity claims made during these proceedings.

Jan Cornelitz came to the Cape in 1666 and married Catharina Harmansz on 22 May $1672[8,9$, Supplementary Table 1]. They had three children but she must have passed away before 1683 , because on the $11^{\text {th }}$ of July 1683 Jan got married to Maria Kickers [8,9, Supplementary Table 1, Figure 1]. Maria and Jan's first child, Theunis, was christened on the $15^{\text {th }}$ of April 1686, almost three years after their marriage date [8,9, Supplementary Table 1]. A second son followed shortly and was christened on the $2^{\text {nd }}$ of November 1687 [8,9]. But in May 1689 Jan gathered together two female witnesses that testified that Maria told them that her first child was in fact fathered by Ferdinandus Appel and the second child by Frederik Botha (also known as Both and Boot) [7, Supplementary Table 1]. At the time of conception Ferdinandus was 20 years old and unmarried [8] whereas Frederik farmed part of Jan's land for him from 1686 [5]. The reason for these testimonies was presumably to rein Maria in. Between these testimonies and their divorce eleven years later, Maria had a further five children [8,9]. Some popular accounts claim that Maria and Frederik openly christened the children together, but in fact, for all six children's christenings that could be verified in the registers Jan was named as the father and Maria as mother (Supplementary Table 1).

In 1700 Jan seems to have had enough of Maria's relationship with Frederik and filed for a divorce. Here Maria admitted to having had all her children with Frederik Botha and blamed her husband for being impotent and suggested that he even encouraged her [5,6,7]. Maria was not given permission to remarry. In 1702 the Muster roll gives Frederik living with 8 children, presumably those of Maria, and Maria living on her own in Stellenbosch. This record may have been a subterfuge to prevent authorities from learning that Maria and Frederik were illegally co- 
habiting. In 1706 they were indeed found guilty of co-habiting (Supplementary Table 1). After Jan's death in 1713, Maria and Frederik finally got married in $1714[8,9]$.

In the end, all Maria's children used the surname Botha rather than the name they were christened under [7]. While we may not know the paternity of Maria's children we know that her descendants did extremely well at the Cape. The Bothas grew into the second largest Afrikaner family with 76,125 living people carrying this surname in South Africa today (number supplied by Department of Home Affairs, Republic of South Africa). Famous Botha's include the politicians/statesmen General Louis Botha, Minister Pik Botha and President PW Botha. In addition to the patrilineal descendants carrying the surname Botha, the Botha daughters of each generation left an even deeper footprint on the Afrikaner heritage. It is common for Afrikaners to be related to Frederik Botha and Maria Kickers several times (JMG is related to them by 18 times [10]). Curiously the Appel family did not amount to much in terms of descendants and there are very few Appels in South Africa today. For instance, the Pretoria phone directory lists 8 Appels, but about 1100 Bothas.

Unfortunately the paternity of Maria's three daughters during her marriage with Jan will never be known. For her four sons however, we can use the non-recombining part of the Ychromosome region to test if her sons descend from the same patriline [1,2]. Of course, this will only be true if adulterous relationships in later generations did not result in a mismatch of haplotypes. Fortunately, the Afrikaner population has an extremely low non-paternity rate of $0.8 \%$ [11] which means that direct male descendants will have a high probability of sharing the same Y-chromosome haplotype, even 10 generations later $\left(92 \%\right.$ chance $\left.=(1-0.008)^{10}\right)$.

Not surprisingly several histories conclude that Ferdinandus Appel did indeed father the first son [6,7] while others do not mention Appel at all $[5,8,9]$ and all of these assume that Jan did not father any of Maria's children. The fact is that without DNA evidence, not even Maria herself may have known who the father was. Here we use the Y-filer STR kit to genotype randomly sampled male Bothas and patrilineal male descendants from each of Maria Kickers's four sons to clarify their paternity.

\section{Materials and Methods}

Ethical clearance for data collection and writing this paper was obtained from the Ethics Committee of the Natural and Agricultural Faculty, University of Pretoria (EC11912-065 and EC130110-001). All subjects were given a study information sheet and filled in and signed a consent form. 
Samples were collected with Oragene ${ }^{\circledR}$ DNA Saliva collection kits (DNA Genotek, Kanata, Canada) and whole genome DNA was extracted according to manufacturer's instructions. Seventeen short tandem repeat (STR) loci were PCR amplified with the AmpFESTR $^{\circledR}$ Yfiler $^{\mathrm{TM}}$ kit (Applied Biosystems, Foster City, USA) and length variation for these loci were determined with the 3500xl Genetic Analyzer (Applied Biosystems, Foster City, USA).

While the details of this divorce case were discussed in a popular magazine in 1926 [5], only a few genealogists know about the controversy surrounding Maria's divorce, let alone the contested paternity of her children. Since all her children adopted the surname Botha, the existence of Jan Cornelitz is forgotten by all but a few. Students and staff from the University of Pretoria with the surname Botha were contacted in person or via email, told about the study, and asked if they want to participate. Fifteen of these participated and we screened the ancestry information they gave to ensure that no close relatives were sampled. We do not have any reason to believe that any of Maria's sons' ancestors were more likely to participate than any other and we believe this to be a random sample. These 15 men were typed to determine if there was evidence for a non-paternity event early in the family's history. The haplotypes were entered on YHRD website [12] to gauge how common these haplotypes are among European men. It is tempting to use South African frequency samples but this would be misleading as a founder effect occurred at the Cape [10] and the current haplotype frequencies would be very misleading. European haplotype frequencies would be a more accurate reflection of haplotype frequencies circulating at the Cape in the late 1600's.

In order to test if all Maria's sons had the same father or not genealogists put us into contact with living male descendants of each of her sons. One male from the random sample knew how he linked up to Maria's sons and he was included here. In this way three descendants of each of her first two sons, one of her third and two of her fourth son were typed (Figure 1). These male descendants with the surname Botha were removed from the sons by as many as nine generations. Afrikaner genealogies are well recorded from church records [8,9] with an active genealogical community. Therefore we have a high degree of certainty that these nine Botha descendants of Maria have been linked to her four sons correctly. By obtaining haplotypes of different patrilines of her first two sons we can have a high certainty of inferring the haplotype of her sons.

Several Appels immigrated to the Cape [9] but they left very few descendants. We phoned Appels listed in the Pretoria and Cape Peninsula telephone directories and after eliminating some potential participants due to recent immigration two samples were obtained. If 
either or both of these match the haplotype of Theunis's descendants it would indicate that Fredinandus Appel may have been Theunis's father.

To visualise the haplotypes detected, a median-joining network was constructed with Network v4.6.1.1 (Fluxus Technology) [13,14,15]. The DYS385 loci (a and b) were excluded and the inverse of the variance was used to weight the remaining markers (Fgure 2). The haplogroups for the y-chromosome STR profiles were estimated with the Whit Athey haplogroup predictor $[16,17,18]$.

\section{Results and Discussion}

The random Botha sample show two distinct STR profiles estimated to belong to the R1b haplogroup and differing at five of the 17 loci in roughly equal proportions (Table 1, Figure 2) suggesting that there may have been an early instance of non-paternity in the family's history. The deep rooting pedigree of the patrilineal descendants of Maria's four sons shows that this can be explained by her first son having had a different father from the last three (Figure 1). The pedigree-linked samples also show that the last three sons had the same father (Figure 1). These data contradict Maria's testimony that all her children were fathered by one man, Frederik Botha. Maria probably lied about this to counter her husband's argument that she was licentious and Frederik could have gone along with it to protect Maria's name.

There was only one mutational step between the one Botha haplotype and one of the Appel males (Table 1, Figure 2). This haplotype was not observed in the European sample so we will conservatively assume that the haplotype frequency is equal to the upper $95 \% \mathrm{CI}$ of the allele frequency of $1.914 \times 10^{-4}$. The chances that two men descended from the same ancestor, separated by about 20 generations are identical at loci 1 to 16 , but not at locus 17 , is given by the multinomial distribution as: $20\left[\prod_{i=1}^{16}\left(1-p_{i}\right)^{20}\right]\left(1-p_{17}\right)^{19} p_{17} / 2$, with $\mathrm{p}_{\mathrm{i}}=$ the mutation rate of the ith locus [19]. Erasmus \& Greeff (unpublished results) estimated the mutation rates for these loci in over a thousand father son transmissions in this population and found them to be very close to former estimates [20]. Inserting the appropriate values into the equation gives a probability of 0.0249 . It is thus 130 times more likely that the descendants of Theunis are linked by male descent to the living man with the surname Appel than Theunis being a descended from another immigrant that just happened to have the same haplotype by chance. The concordance between the old ladies' testimonies and the haplotype match with a living Appel makes a compelling case that Ferdinandus Appel was Maria's first child's father. 
Given that Maria was adamant that all her children were by Frederik Botha and that Jan divorced her, it seems parsimonious to assume that the last three sons were Frederik's rather than Jan's. Even though Jan had a son by his first wife [8], this son did not leave any descendants to allow for a comparison with the Botha descendants. It is thus impossible to rule out Jan with $100 \%$ certainty.

Such an early non-paternity can explain why the Botha family has two haplotypes in roughly equal proportions (proportion $=0.53 ; 95 \% \mathrm{CI}$ : $0.27-0.79$ ). Looking at the Botha patrilines it becomes evident that Theunis left as many male descendants as his three halfbrothers combined (Figure 2). It would be ironic if almost half the people with the surname Botha (38,000 people), a common Afrikaans surname, are actually Appel descendants, a very rare surname.

An alternative explanation for observing two Botha DNA signatures could be that the one profile belonged to descendants of Samuel Friedrich Bode whose descendants are also known as Botha. However, Samuel only arrived at the Cape in 1767, got married in 1776 and his first and only son was born in 1784. By then, Frederik's male descendants already numbered in the 70's (Figure 2). While we may expect to sample one of Samuel's descendants in a random sample of 15 , it is extremely unlikely to have sampled 7 of his descendants. Furthermore, the matches with known descendants of both sets of brothers show that these haplotypes descend from Maria's sons.

At the divorce case Maria claimed that Jan was "onbequaamd" which could either mean that he was impotent or sterile. Three children with his first wife suggest that Jan was not sterile. However, with advanced age men are more likely to suffer from impotence [21]. Indeed, Jan was Maria's senior by at least 20 years because he already arrived in the Cape in 1666 and he was absolved from military duty in 1703 on account of his advanced age (Supplementary Table 1). While eighty percent of newly wed couples at the Cape christened their first child within two years of their marriage date [22] Maria's first child was only christened on the $15^{\text {th }}$ of April 1686, almost three years after their marriage [Supplementary Table 1; 8,9]. These facts in addition to the fact that Jan waited so long to ask for a divorce, that only one haplotype in addition to the Appel-like one was found among Maria's sons and that the children adopted the Botha name rather than the name with which they were christened, suggest that Jan may well have been impotent. The 1689 testimonies (Supplementary Table 1) may have been a desperate attempt to stop Maria and Frederik's affair. However, it may have been the case that the prospect of partible inheritance [23] and being ridiculed for being impotent may have led to the 
situation where Jan avoided the divorce leading to a less and less tenable situation where Frederik conceived child after child with Maria with Jan's full knowledge.

It is unclear if Ferdinandus and Theunis knew that they were father and son. The fact that Maria told at least two ladies about Ferdinandus (one of whom was Ferdinandus's future wife's aunt) and that they testified to this effect, suggests that there was opportunity for Ferdinandus to be cognisant of his paternity. Ferdinandus was a strident man with a deep friendship with the rebel leader Adam Tas [24], serving as a heemraad (a member of a council that assisted the magistrate in governance of rural districts), and he was also prosperous leaving behind a large estate. In these regards Theunis certainly took after his biological father with Boeseken describing him as being a "public spirited man" with public involvement as a heemraad and several loan farms to his name [7]. It is ironic that two of the most well-known Bothas, Louis Botha, who was a general and commander-in-chief of Transvaal Boers during the second Boer War and later the first Prime minister of the Union of South Africa, and P.W. Botha, who was prime minister of South Africa from 1978 to 1984 and the first executive state president from 1984 to 1989 , were both in fact direct male descendants of Ferdinandus Appel.

\section{Conclusions}

By combining deep-rooting pedigrees with Y-chromosome haplotypes we could show that Maria's first son was most probably fathered by Ferdinandus Appel, whereas her remaining three sons were probably fathered by Frederik Botha. Maria's first son, Theunis, and his sons were all very fecund resulting in roughly half the living Botha men being descendants of Ferdinandus rather than Frederik. Jan Cornelitz's behaviour suggests that he may well have been impotent. Although we did illustrate that Maria Kickers had an adulterous relationship, this was certainly not the norm for married couples at the Cape [11]. While the frequencies of all the haplotypes were very low, we concur with Kayser et al. [2] that the limited population data restricts the accuracy of estimates and inferences.

\section{Acknowledgements}

We thank Joe Botha, Janet Melville and Ria Meyer for help and all the Botha and Appel males for donating samples. We would like to thank Richard Ball for guidance, advice and information pertaining to historical events and two referees for their helpful suggestions. We thank Jonas Mabetwa and Shoki Mphokane from South African Home Affairs for information on the number of living Bothas. This work was supported by grant 77256 from the National 
Research Foundation to JMG. Any opinion, findings and conclusions or recommendations expressed in this material are those of the authors' and therefore the NRF do not accept any liability in regard thereto.

\section{References}

[1] E.A. Foster, M.A. Jobling, P.G. Taylor, P. Donnelly, P. de Knijff, R. Mieremet, T. Zerjal, C. Tyler-Smith. Jefferson fathered slave's last child, Nature 396 (1998) 27-28.

[2] M. Kayser, M. Vermeulen, H. Knoblauch, H. Schuster, M. Krawczak, L. Rœwer, Relating two deep-rooted pedigrees from central Germany by high-resolution Y-STR haplotyping, Forensic Sci. Int. Genet. 1 (2007) 125-128.

[3] Z. Hawass, Y.Z. Gad, S. Ismail, R. Khairat, D. Fathalla, N. Hasan, A. Ahmed, H. Elleithy, M. Ball, F. Gaballah, S. Wasef, M. Fateen, H. Amer, P. Gostner, A. Selim, A. Zink, C.M. Pusch, Ancestry and pathology in King Tutankhamun's family, J. A. M. A. 303 (2010) 638-647.

[4] C.M. Bauer, M. Bodner, H. Niederstätter, D. Niederwieser, G. Huber, P. HatzerGrubwieser, K. Holubar, W. Parson, Molecular genetic investigations on Austria's patron saint Leopold III, Forensic Sci. Int. Genet. 7 (2013) 313-315.

[5] J.L.M. Franken, Die Franse vlugtelinge, Huisgenoot (16 July 1926) 36-38.

[6] G.C. de Wet, Die vryliede en vryswartes in die Kaapse nedersetting 1657-1707, Historiese Publikasie Vereniging, Kaapstad, 1981.

[7] A. Böeseken, M. Cairns, The secluded valley: Tulbagh: 't land van waveren, 1700-1804, Perskor, Cape Town, 1989.

[8] C.C. de Villiers, C. Pama, Genealogies of Old South African Families. vol I A - K, A.A. Balkema, Cape Town, 1966.

[9] J.A. Heese, R.T.J. Lombard, South African Genealogies 1, A-C, Human Sciences Research Council, Pretoria, 1986.

[10] J.M. Greeff, Deconstructing Jaco: genetic heritage of an Afrikaner. Ann. Hum. Genet. 71 (2007) 674-688.

[11] J.M. Greeff, F.A. Greeff, A.S. Greeff, L. Rinken, D.J. Welgemoed, Y. Harris, Low nonpaternity rate in an old Afrikaner family. Evol. Hum. Behav. 33 (2012) 268-273.

[12] S. Willuweit, L. Roewer, Y chromosome haplotype reference database (YHRD): update, Forensic Sci. Int.-Genet. 1 (2007), 83-87.

[13] Network software website: http://www.fluxus-engineering.com/sharenet.htm 
[14] Polzin, T., and Vahdati, S., On Steiner trees and minimum spanning trees in hypergraphs. Oper. Res. Lett. 31 (2003) $12-20$.

[15] Bandelt, H.J., Forster, P., Röhl, A., Median-joining networks for inferring intraspecific phylogenies. Mol. Biol. Evol. 16 (1999) 37-48.

[16] Whit Athey haplogroup predictor website: http://www.hprg.com/hapest5/index.html

[17] Athey, T.W., Haplogroup prediction from Y-STR values using an allele-frequency approach. JoGG 1 (2005) 1-7.

[18] Athey, T.W., Haplogroup prediction from Y-STR values using a Bayesian-allele-frequency approach. JoGG 2 (2006) 34-39.

[19] B. Rolf, W. Keil, B. Brinkmann, L. Roewer, R. Flimmers, Paternity testing using Y-str haplotypes: assigning a probability for paternity in cases of mutations. Int. J. Legal Med. 115 (2001) 12-15.

[20] M. Goedbloed, M. Vermeulen, R.N. Fang, M. Lembring, A. Wollstein, K. Ballantyne, O. Lao, S. Brauer, C. Krüger, L. Roewer, R. Lessig, R. Ploski, T. Dobosz, L. Henke, J. Henke, M.R. Furtado, M. Kayser, Comprehensive mutation analysis of 17 Ychromosomal short tandem repeat polymorphisms included in te AmpFiSTR ${ }^{\circledR}$ Y filer ${ }^{\circledR}$ PCR amplification kit, Int. J. Legal Med. 123 (2009) 471-482.

[21] H.A. Feldman, I. Goldstein, D.G. Hatzichristou, R.J. Krane, J.B. McKinlay, Impotence and its medical and psychosocial correlates: results of the Massachusetts Male Aging Study J. Urol. 151 (1994) 54-61.

[22] R. Ross, The "white" population of South Africa in the eighteenth century, Pop. Stud. 29 (1975) 217-230.

[23] H. Giliomee, "Allowed such a state of freedom": women and gender relations in the Afrikaner community before enfranchisement in 1930. New Contree, 59 (2010) 29-60.

[24] A. Tas, The diary of Adam Tas; 1705-1706. Ed. L. Fouché; revised A.J. Böeseken; Van Riebeeck Society, Cape Town, 1970. 
Figure 1. The pedigree of patrilines showing how each male sampled (squares at bottom) link up to Maria Kickers's four sons. $\mathrm{x}$ demarcates a marriage and the date above the $\mathrm{x}$ is the marriage date and the dates under names are their christening dates. The number letter combination refers to the Botha haplotype in Table 1.

Figure 2. The network of the Y-STR haplotypes for the random and pedigree-linked Botha and Appel samples. Each mutation is indicated by a short line crossing the line connecting two haplotypes. Therefore a single line indicates a single mutational difference between two haplotypes. The random Botha sample that could be linked to the second son with genealogical data is included in the second to fourth sons' category. The Appel sample that is five mutational steps away from all samples were excluded.

Figure 3. Patrilines (or male lineages of descent) for the families Botha (B) and Appel (A) for all males born before 1780. The black lines indicate all the descendants of Frederik Botha whereas the grey lines indicate the descendants of Ferdinandus Appel (including Maria's first son Theunis). X indicates the wedding date of Samuel F. Bode, whose only son was born in 1782. Compiled from $[6,7]$. 
Figure 1

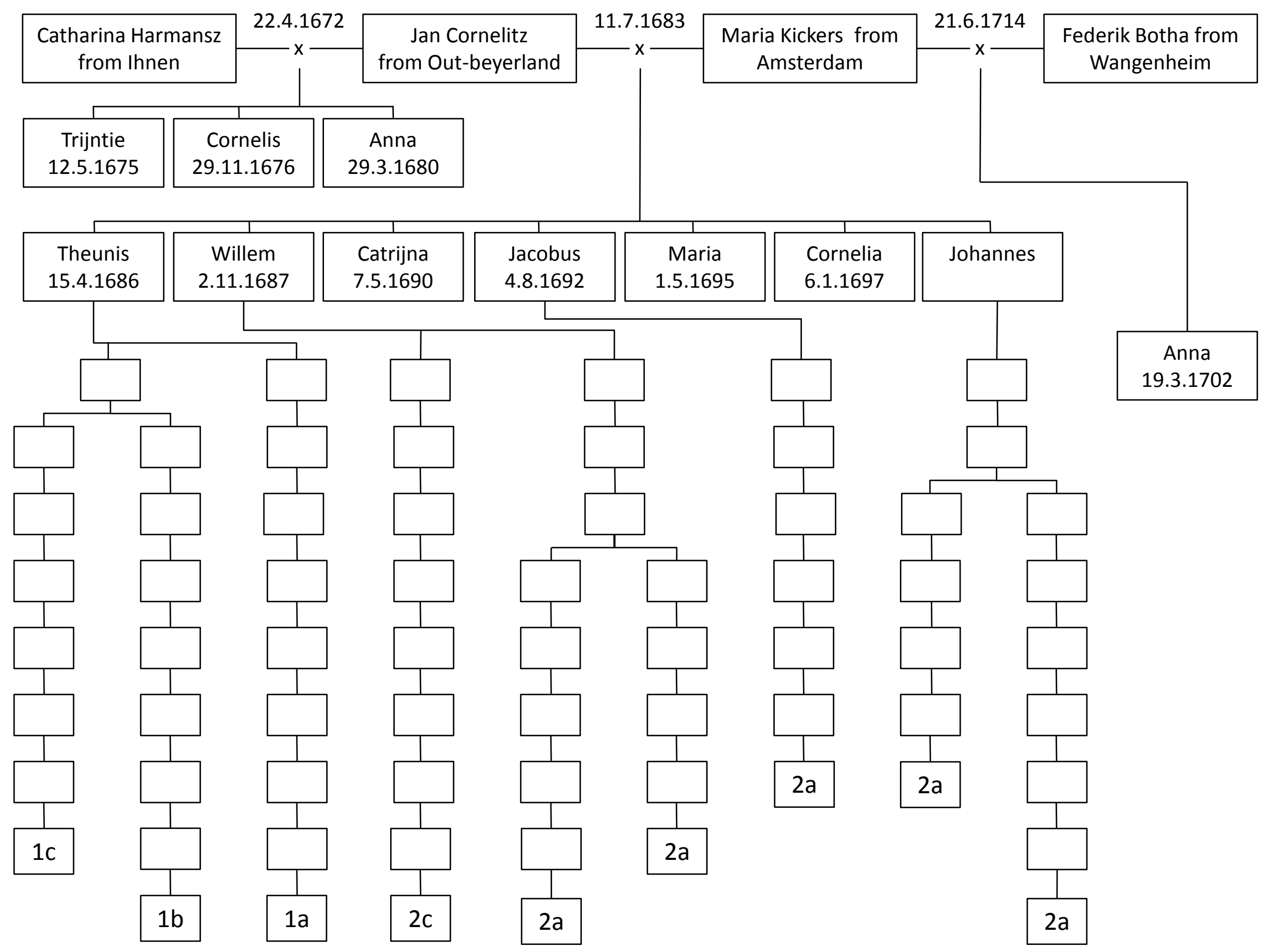


Figure 3

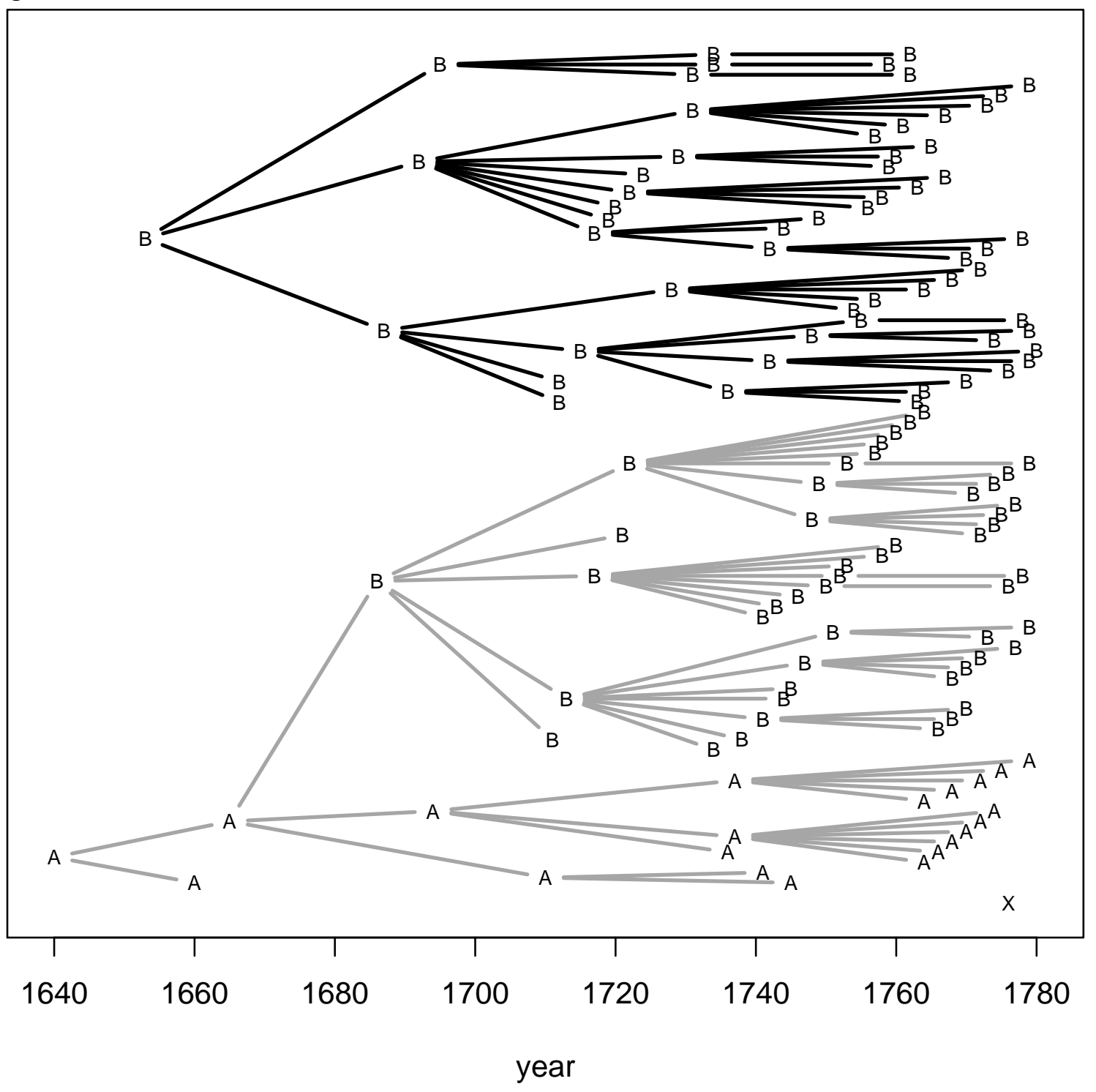


Table 1. The number of repeats at each of the 17 STR loci. The number of males of each haplotype in the random Botha sample is given under n1 whereas the number of males bearing each haplotype in the pedigree-linked samples of figure 1 is given under $n 2$. Match indicate the number of matches on the YHRD website out of 19276 men from Eurasian subpopulations. * = number of repeats identical to the Botha 2a or Botha 1a haplotypes. The underlined numbers show loci where the two main Botha types differ. Italic numbers show instances where Appel 2 differs from Botha 1.

\begin{tabular}{|c|c|c|c|c|c|c|c|c|c|c|c|c|c|c|c|c|c|c|c|c|}
\hline Name & $\mathrm{n} 1$ & $\mathrm{n} 2$ & Match & $\begin{array}{c}\text { DYS } \\
19\end{array}$ & $\begin{array}{l}\text { DYS } \\
385 a \\
\end{array}$ & $\begin{array}{l}\text { DYS } \\
385 b\end{array}$ & $\begin{array}{l}\text { DYS } \\
3891 \\
\end{array}$ & $\begin{array}{c}\text { DYS } \\
389 I I\end{array}$ & $\begin{array}{c}\text { DYS } \\
390 \\
\end{array}$ & $\begin{array}{c}\text { DYS } \\
391\end{array}$ & $\begin{array}{l}\text { DYS } \\
392\end{array}$ & $\begin{array}{l}\text { DYS } \\
393\end{array}$ & $\begin{array}{c}\text { DYS } \\
437\end{array}$ & $\begin{array}{c}\text { DYS } \\
438 \\
\end{array}$ & $\begin{array}{c}\text { DYS } \\
439\end{array}$ & $\begin{array}{c}\text { DYS } \\
448\end{array}$ & $\begin{array}{c}\text { DYS } \\
456\end{array}$ & $\begin{array}{c}\text { DYS } \\
458\end{array}$ & $\begin{array}{c}\text { DYS } \\
635\end{array}$ & $\begin{array}{c}\text { GATA- } \\
\text { H4 }\end{array}$ \\
\hline Botha $2 \mathrm{a}$ & 7 & 5 & 4 & 14 & 11 & 14 & 13 & 29 & 25 & 11 & 13 & 13 & 15 & 12 & 12 & 19 & 15 & 17 & 23 & 12 \\
\hline Botha $2 b$ & 1 & 0 & 0 & $*$ & $*$ & $*$ & $*$ & $*$ & $*$ & 10 & $*$ & $*$ & $*$ & $*$ & $*$ & $*$ & $*$ & $*$ & $*$ & $*$ \\
\hline Botha 2c & 0 & 1 & 0 & * & $*$ & 12 & * & $*$ & * & $*$ & $*$ & * & 14 & $*$ & $*$ & * & * & $*$ & $*$ & * \\
\hline Botha 1a & 6 & 1 & 0 & 14 & 11 & 14 & 13 & $\underline{30}$ & 23 & 11 & 13 & 13 & 15 & 12 & $\underline{11}$ & 19 & 15 & $\underline{19}$ & 23 & $\underline{11}$ \\
\hline Botha $1 \mathrm{~b}$ & 1 & 1 & 0 & $*$ & $*$ & $*$ & $*$ & $*$ & $*$ & 12 & $*$ & $*$ & $*$ & $*$ & $*$ & $*$ & $*$ & $*$ & $*$ & $*$ \\
\hline Botha 1c & 0 & 1 & 0 & * & $*$ & $*$ & * & $*$ & $*$ & $*$ & $*$ & * & $*$ & $*$ & $*$ & * & * & 18 & $*$ & $*$ \\
\hline Appel 1 & & & 0 & $*$ & $*$ & $*$ & $*$ & $*$ & $*$ & $*$ & $*$ & $*$ & $*$ & $*$ & $*$ & $*$ & 16 & $*$ & $*$ & $*$ \\
\hline Appel 2 & & & 0 & 14 & 11 & 13 & 13 & 30 & 24 & 11 & 13 & 13 & 14 & 12 & 13 & 18 & 15 & 17 & 24 & 11 \\
\hline
\end{tabular}


Supplementary Table 1. Translations of original documents and references to the appropriate archives. Most of these were copied from Richard Ball's web site http://www.ballfamilyrecords.co.uk, following his suggestion.

\begin{tabular}{|c|c|c|}
\hline Year & Event & Source \\
\hline 1666 & $\begin{array}{l}\text { Jan Cornelitz from Oudtbeijerland arrived at the Cape in } 1666 \text { as a sailor on the ship } \\
\text { Walcheren, after which he was freed to work for the freeburgers, but in } 1670 \text { he asked to } \\
\text { be taken back into the Company service under a three year contract at } 13 \text { guldens per } \\
\text { month, and then to become a farmer. }\end{array}$ & $\begin{array}{l}\text { http://databases.tanap.net/cgh/ } \\
\text { Resolutions of the Council of Policy of Cape of Good } \\
\text { Hope, Cape Town Archives Repository, South Africa } \\
\text { C. 6, pp. 24-65, } 5 \text { March } 1670\end{array}$ \\
\hline 1672 & $\begin{array}{l}\text { marriages, } 167222 \text { May } \\
\text { Jan Cornelisz, young man born in Out-beyerland, with Catharina Harmansz from Ihnen. }\end{array}$ & $\begin{array}{l}\text { Church Register - Cape Town Congregation, Cape } \\
\text { Archives, VC 603, VC 604, VC 605, VC } 644\end{array}$ \\
\hline 1683 & $\begin{array}{l}\text { marriages, ao' } 1683 \text { eodem dito (11 July) Jan Cornelisz free man from Outbeierlant and } \\
\text { young woman Maria Kickers }\end{array}$ & $\begin{array}{l}\text { Church Register - Cape Town Congregation, Cape } \\
\text { Archives, VC 603, VC 604, VC 605, VC } 644\end{array}$ \\
\hline 1686 & baptisms, 15 dito (April) Theunis Jan Cornelis van Outbeierland and Maria Kickers & $\begin{array}{l}\text { Church Register - Cape Town Congregation, Cape } \\
\text { Archives, VC 603, VC 604, VC 605, VC } 644 \\
\text { baptisms, page 30, } 1686\end{array}$ \\
\hline 1687 & $\begin{array}{l}2 \text { September christened at Stellenbosch and named Willem whose father is Jan Cornelisz } \\
\text { from Outbeijerland and whose mother is Marij Kickers, as witness Willem van } \\
\text { Emmerhorst }\end{array}$ & $\begin{array}{l}\text { Church Register - Cape Town Congregation, Cape } \\
\text { Archives, VC 603, VC 604, VC 605, VC } 644 \\
\text { baptisms, page 32, } 1687\end{array}$ \\
\hline 1689 & $\begin{array}{l}\text { On today the } 13 \text { May } 1689 \\
\text { Sworn to before me the undersigned Sibrandus Mancadan secretary to Stellenbosch at the } \\
\text { request of Belijtie Fredericks wife of the freeburger Harmen Jansen from Noorthorn } \\
\text { dwelling at Stellenbosch, the honourable Hendrik Cornelis and the honourable Catrijn } \\
\text { Cloeten in the presence of the undernamed witnesses admitting and declaring and attesting } \\
\text { true and true to be, that she, the attestator, during the pregnancy of Maria Kickers (now } \\
\text { four years in the past) from the mouth of the aforesaid Maria Kickers had heard, that the } \\
\text { child with which she was pregnant, did not belong to her husband Jan Cornelis but to } \\
\text { Frederik Boot, using in essence these words: that she did not belong to all men, but kept } \\
\text { herself to one, and that Frederik Boot was the father of the child with which she was now } \\
\text { pregnant, and also the father of her first child was that of Ferdinandus Appel. In similar } \\
\text { fashion was declared by Beatrix Gijsberts declaring that at this same time the } 11 \text { August } \\
1685 \text { (it was a Sunday to the attestator's best knowledge) likewise from the aforesaid } \\
\text { Maria Kickers to have heard, that Frederick Boot had known her, and that she from that } \\
\text { time on had become pregnant. }\end{array}$ & $\begin{array}{l}\text { 1/STB 18/144 Gemengde Notariele Aktes:Verklaring, } \\
\text { 12.8.1699, geen paginering; 1/STB 18/152 Notariele } \\
\text { Verklarings, 13.5.1689, geen paginering. }\end{array}$ \\
\hline
\end{tabular}




\begin{tabular}{|c|c|c|}
\hline 1690 & $\begin{array}{l}7 \text { May one child christened of whom the father is Jan Cornelisz from Oudtbeierlandt, and } \\
\text { the mother is Maria Kikkers, with the name, Catrijna. }\end{array}$ & $\begin{array}{l}\text { Church Register - Cape Town Congregation, Cape } \\
\text { Archives, VC } 603 \text {, VC } 604 \text {, VC } 605 \text {, VC } 644 \\
\text { baptisms, page } 40,1690\end{array}$ \\
\hline 1692 & $\begin{array}{l}24 \text { Augus; One child christened as Jacobus of whom the father was Jan Cornelisze of } \\
\text { Outbeirlant, and whose mother was Maria Kikkers, as witnesses are Hans Hendrik Smith } \\
\text { and Aeltie Klaaz. }\end{array}$ & $\begin{array}{l}\text { Church Register - Cape Town Congregation, Cape } \\
\text { Archives, VC 603, VC 604, VC 605, VC } 644 \\
\text { baptisms, page 46, } 1692\end{array}$ \\
\hline 1695 & $\begin{array}{l}1 \text { May a child of Jan Cornelisse and Maria Kikkers named Maria, as witnesses Hendrik } \\
\text { Janse Brouwer and Aeltje Claas }\end{array}$ & $\begin{array}{l}\text { Church Register - Cape Town Congregation, Cape } \\
\text { Archives, VC 603, VC 604, VC 605, VC } 644 \\
\text { baptisms, page 56, } 1695\end{array}$ \\
\hline 1697 & $\begin{array}{l}\text { Cornelija daughter of Jan Corenelisz the mother is Marij Kickers was christened on } 6 \\
\text { January 1697, as witnesses Jan Jacobs and Cornelia Helmes }\end{array}$ & $\begin{array}{l}\text { Church Register - Stellenbosch Congregation, } \\
\text { Consulted both as microfilm at the LDS and } \\
\text { Palmkronieke facsimile, also Cape Archives verbatim } \\
\text { copies, originals at the Nederduits Gereformeerde } \\
\text { Kerk Argief, Stellenbosch, G2 4/1, VC } 639 \text { baptisms, } \\
\text { page } 11\end{array}$ \\
\hline 1700 & $\begin{array}{l}\text { Jan Cornelisze of Oud Beijerland, freeburger residing in Stellenbosch, claimant in divorce } \\
\text { case } \\
\text { vs } \\
\text { his wife Maria Kickers, defendant. } \\
\text { Presided by Honorable Mr Governor Captain Oelof Berg and Ensign Ambrosius Zaffee } \\
\text { representing mayor Burgert Mensinck. } \\
\text { Claimant states that defendant embarrasses claimant not only by regular pushing and } \\
\text { shoving and further disgusting behavior, but also by committing adultery with Frederick } \\
\text { Boot. } \\
\text { Claimant asks permission to terminate his marriage and to marry another. Claimant } \\
\text { submits documentation to support his claim. } \\
\text { Defendant admits that her children are not fathered by her husband (due to his incapacity) } \\
\text { but by Frederick Boot, and that her husband had in fact encouraged her infidelity. } \\
\text { Defendant confirms her confession to the Stellenbosch magistrate. } \\
\text { Claimant disputes that his behaviour was the reason for defendant's actions but accepts } \\
\text { that her confession will be to his advantage. } \\
\text { Both parties close arguments. } \\
\text { The court, having heard both parties as well as Frederick Boot's confession and taking }\end{array}$ & $\begin{array}{l}\text { (Crim. and Civ. 1689-1701, } 22 \text { Jan. 1700, p. 77) } \\
\text { Original transcript: } \\
\text { Vrijdag den 22' Januarij } 1700\end{array}$ \\
\hline
\end{tabular}




\begin{tabular}{|c|c|c|}
\hline & $\begin{array}{l}\text { into account defendant's confession, orders separation of claimant's and defendant's } \\
\text { marital ties and possessions, permits claimant to marry another and allocates costs to } \\
\text { parties involved. } \\
\text { Good Hope Castle. } \\
\text { Melchoir Kemels } \\
\text { (secretary) }\end{array}$ & \\
\hline 1701 & $\begin{array}{l}\text { lists Frederik living in Stellenbosch with eight children, and Maria listed on her own but } \\
\text { also in Stellenbosch, apparently living apart from them. }\end{array}$ & The muster roll of 1701 (dated 31st January 1702) \\
\hline 1702 & $\begin{array}{l}\text { Anna daughter of Frederik Both, the mother being Maria Kickers (there is no date but the } \\
\text { entry is between baptisms on } 19 \text { March } 1702 \text { and } 9 \text { April 1702) }\end{array}$ & $\begin{array}{l}\text { Church Register - Stellenbosch Congregation, } \\
\text { Consulted both as microfilm at the LDS and } \\
\text { Palmkronieke facsimile, also Cape Archives verbatim } \\
\text { copies, originals at the Nederduits Gereformeerde } \\
\text { Kerk Argief, Stellenbosch, G2 4/1, VC } 639 \text { baptisms, } \\
\text { page } 37\end{array}$ \\
\hline 1703 & $\begin{array}{l}\text { On the } 21 \text { st May } 1703 \text { Jan Cornelitz was absolved by the Militia Council from military } \\
\text { duty on account of his advanced age. }\end{array}$ &.$(1 \mathrm{STB} 15 / 2)$ \\
\hline 1706 & $\begin{array}{l}\text { Maria and Frederick were found guilty of co-habiting (Richard Ball's comment: "as far as } \\
\text { I can gather because this still constituted adultery on her part, even though her husband } \\
\text { had divorced her in } 1700 \text {, presumably because she was not given leave to marry again. } \\
\text { Before this court she declared, rather endearingly, it seems to me, that she and Frederick } \\
\text { had sworn troth to each other, just as though they were truly married to each other and that } \\
\text { they had lived together for several years as man and wife, and had together produced eight } \\
\text { children. The court was not impressed."), of keeping and hiding stock, and for assaulting } \\
\text { Claas Das. They were banned separately to Mauritius for } 10 \text { years and were fined } 100 \\
\text { Rds. It is unclear if the first part of the sentence was ever followed through on. }\end{array}$ & (Crim. and Civ. 1701-'08, 16 Nov. 1706. f.47). \\
\hline 1713 & Generale Kassarekeningen 1689-1724 1713 Jan Cornelisz van Oudbeijerland f6 & $\begin{array}{l}\text { Malan, O.G. - Verlore Dokumentasie oor die } \\
\text { Gemeente Stellenbosch van } 1689 \text { tot 1725, In: } \\
\text { Capesis, issue no. 2, } 2002\end{array}$ \\
\hline 1714 & $\begin{array}{l}\text { marriages, page 9, 1714, } 21 \text { June, Fredrik Bota, young man from Wagenheim with Maria } \\
\text { Kickers van Amsterdam }\end{array}$ & $\begin{array}{l}1 \text { Church Register - Stellenbosch Congregation, } \\
\text { Consulted both as microfilm at the LDS and } \\
\text { Palmkronieke facsimile, also Cape Archives verbatim } \\
\text { copies, originals at the Nederduits Gereformeerde } \\
\text { Kerk Argief, Stellenbosch, G2 4/1, VC } 639\end{array}$ \\
\hline 1735 & $\begin{array}{l}\text { Will - Botha, Theunis \& Maria Catharin van Eeden - 1735, Heemraad and Captain of the } \\
\text { burger commando. Theunis Bota, from the Cape of Good Hope }\end{array}$ & $\begin{array}{l}\text { Cape Archives, MOOC 7/1/7, } 8 \text {; dated 16th July } \\
1735 \text {, filed } 26 \text { July } 1746 \text {, will }\end{array}$ \\
\hline 1739 & 1739, Maanday 31 Augustus: They depart from captain Botha's homestead with one party & Resolutions of the Council of Policy of the Cape of \\
\hline
\end{tabular}




\begin{tabular}{|l|l|l|}
\hline of men and wagons to Jan Celliers where tents were erected. & $\begin{array}{l}\text { Good Hope, } \\
\text { http://www.tanap.net/content/activities/resolutions_C } \\
\text { apeOfGoodHope/, Cape Archives C. 112, pp. 3-33, } \\
\text { Saturdag den 31 October 1739 }\end{array}$ \\
\hline
\end{tabular}

